\title{
21. Yüzyıl Becerileri Açısından Sosyal Bilgiler Öğretmenliği Lisans Programının Değerlendirilmesi
} Fisun BOZKURT ${ }^{1}$

- Geliş Tarihi: 12.02.2020 • Kabul Tarihi: 07.07.2020 • Çevrimiçi Yayın Tarihi: 14.07.2020

\section{$\ddot{\mathbf{O} z}$}

Açımlayıcı karma yöntemin kullanıldığı bu araştırmanın amacı, mevcut sosyal bilgiler öğretmenliği lisans programının 21. yüzyıl becerilerini kazandırma konusunda ne kadar yeterli olduğunu, öğretmen adaylarının bakış açısıyla ortaya koymaktır. Çalışmanın nicel boyutunda tarama yöntemi, nitel boyutunda olgu bilim yöntemi kullanılmıştır. Nitel verilerin toplanmasında 21. yüzyıl becerileri öğretmen adayı ölçeği, nicel verilerin toplanmasında yarı yapılandırılmış görüşme formu kullanılmıştır. Çalışmanın örneklemini, bir devlet üniversitesinde öğrenim gören 335 sosyal bilgiler öğretmen adayı oluşturmaktadır. Çalışmanın bulguları sosyal bilgiler öğretmenliği lisans programının 21. yüzyıl becerilerinden iş birliği ve iletişim becerilerini kazandırma konusunda daha iyi olduğu ancak küresel bağlantılar ve dijital ortamlarda öğretim becerilerini kazandırma konusunda ise yeterli olmadığını ortaya koymuştur. Ayrıca bulgular 21. yüzyıl becerilerinin sosyal bilgiler öğretmenliği lisans programında kazandırılması amaçlanan beceriler olarak yer almasına rağmen bu becerilerin öğrenme süreçlerinde işe koşulmadığını da ortaya koymuştur. Öğretmen eğiticilerinin sundukları eğitsel yaşantılar, öğretmen adaylarının 21. yüzyıl becerilerini kullanabilmeleri için model olmalıdır. Ayrıca, öğretmen eğitimcilerinin ne öğretildiği kadar içeriğin nasıl öğretildiğinin de önemli olduğu fikrini kavramaları önem arz etmektedir. Özellikle de öğretmen eğitimi programlarında bu becerileri hedef alan detaylı bir programa ve değerlendirmelere yer verilmelidir.

Anahtar sözcükler: 21. yüzyıl becerileri, öğretmen eğitimi, sosyal bilgiler eğitimi, karma yöntem.

\section{Atıf:}

Bozkurt, F. (2021). 21. yüzyıl becerileri açısından sosyal bilgiler öğretmenliği lisans programının değerlendirilmesi. Pamukkale Üniversitesi Eğitim Fakültesi Dergisi, 51, 34-64. doi:10.9779/pauefd.688622

\footnotetext{
${ }^{1}$ Doç. Dr., Pamukkale Üniversitesi, Eğitim Fakültesi, Sosyal Bilgiler Eğitim ABD, Denizli, ORCID: 0000-0001-91018422, E posta: fisunbozkurt@ pau.edu.tr
} 


\section{Giriş}

21. yüzyıl bilgi çerçeveleri için yapılan çağrı, eğitimin öğrencileri 21. yüzyılın taleplerine hazırlama konusunda başarısız olduğu iddiasına dayanmaktadır. Okul (organizasyon, yapı ve format açısından) bugün de 20. yüzyıl boyunca olduğu gibi aynı kalmıştır. Giderek küreselleşen bir ekonominin ihtiyaç duyduğu işgücünün, 20. yüzyılın tekrarlama becerilerini, temel uygulamalı bilgileri ve sınırlı okuryazarlık becerilerini aşan tamamen farklı bir eğitim modeli gerektirdiğini açıkça ortaya koymuştur (Kereluik, Mishra, Fahnoe ve Terry, 2013). Bu beceri ve yeterliliklerin ekonomik ve sosyal kalkınma modellerinin ihtiyaçları doğrultusunda geçen yüzyıla göre daha fazla ortaya çıktıklarını göstermek için bunlara genellikle 21. yüzyıl beceri ve yeterlikleri denir (Ananiadou ve Claro, 2009). 21. yüzyıl becerilerinin öğretilmesi ve öğrenilmesine duyulan ilgiye paralel olarak, eğitim bilimciler 21. yüzyıl becerilerine yönelik bir çerçevenin geliştirilmesi için çaba harcamışlardır. Bu çabalar bir dizi çerçevenin ortaya çıkmasına neden olmuştur. Dünyanın dört bir yanındaki birçok kuruluş bağımsız olarak bu beceriler için çerçeveler geliştirmiştir. Bunlardan bazıları şöyledir:

ABD’de 21. Yüzyıl Becerileri İçin Ortaklık (The Partnership for $21^{\text {st }}$ Century Skills, 2007) 21. yüzyılın bireylerini hazırlamak amacıyla iş dünyasını, eğitim liderlerini ve politikacıları bir araya getiren bir oluşumdur. 21. yüzyılda öğrencileri daha rekabetçi küresel bir ekonomide çalışmaya hazır hale getirmek için bir çerçeve geliştirmiştir. Bu çerçevede öğrenme çıktıları şunları içerir: (1) Temel Konular ve 21. Yüzyıl Temaları; (2) Öğrenme ve Yenilik Becerileri; (3) Bilgi, Medya ve Teknoloji Becerileri; (4) Yaşam ve Kariyer Becerileri (Jia, Oh, Sibuma, LaBanca ve Lorentson, 2016). Bu becerilerin dayandığı anahtar konular; "dil edinimi, okuma ve/ya dil sanatlar, dünya dilleri, sanat, matematik, ekonomi, fen/bilim, coğrafya, tarih, devlet ve vatandaşlık" olarak belirlenmiştir. Daha sonra bu anahtar kelimeler içerisinden 21. yüzyıl disiplinler arası temalar belirlenmiştir. Bu 21. Yüzyıl Temaları; küresel farkındalık, girişimcilik, ekonomik ya da finansal okuryazarlık, vatandaşlık okuryazarlığ 1 , sağlık okuryazarlığı ve çevre okuryazarlığıdır. Ö̆̆grenme ve Yenilik Becerileri; yaratıcılık, eleştirel düşünme ve problem çözme, iletişim ve iş birliği alt becerilerini içerir. Bilgi, Medya ve Teknoloji Becerileri ise; bilgi okuryazarlığı, medya okuryazarlığı ile bilgi ve iletişim teknoloji okuryazarlığı alt becerilerinden oluşur. Yaşam ve Kariyer Becerileri çoğunlukla kişisel beceriler gerektirir; esneklik ve uyum, girişimcilik ve öz yönelim, üretkenlik ve mesuliyet (hesap verebilirlik), liderlik ve sorumluluk (Geisinger, 
2016). Kuruluşundan bu yana, çoğu 21. yüzyıl programlarının geliştirilmesinde bu özel çerçeveye atıfta bulunulmuştur.

21. Yüzyıl Öğrenci Standartları (AASL, 2007) ise, 21. yüzyılda bilgi okuryazarlığını arttırmak için dört beceri bileşeninin önemine vurgu yapmıştır: (1) araştırma, eleştirel düşünme ve bilgi edinme; (2) sonuç çıkarma, karar verme, bilgiyi yeni durumlara uyarlama ve yeni bilgi yaratma; (3) demokratik bir toplumun parçası olarak etik ve üretken bir biçimde katılım ve bilgiyi paylaşma; (4) kişisel ve estetik gelişimi sürdürmek. AASL standartları, her bileşenin içerisinde, öğrencilerin bu standartlara ulaşmasının kanıtı olarak gösterebilecek gerekli becerileri, eğilimleri, sorumlulukları ve öz değerlendirme stratejilerini ana hatlarıyla belirtmiştir (Jia ve diğerleri, 2016).

Başka bir çalışmada ise 21. yüzyıl beceri çerçevelerinin analizini yapılandırmak için Binkley, Erstad, Herman, Raizen, Ripley, Miller-Ricci ve Rumble (2012) tarafından genel bir kavramsal şema oluşturulmuştur. Bu şema dört kategoriye ayrılan on yeteneği tanımlamaktadır. Her ne kadar bu becerilerin bir çerçeveden diğerine tanımlanma ve kümelenme biçimlerinde önemli farklılıklar olsa da aşağıdaki on maddenin tüm yaklaşımları barındıracak kadar geniş ve kapsamlı olduğu kabul edilmektedir:

> Düşünme Yolları: (1) Yaratıcılık ve yenilikçilik, (2) Eleştirel düşünme, problem çözme, karar verme, (3) Öğrenmeyi öğrenme, meta biliş.

> Çalışma Yolları: (4) İletişim, (5) İş birliği (Ekip çalışması)

> Çalışma Araçları: (6) Bilgi okuryazarlığı (kaynaklar, kanıtlar, önyargılar vb. ile ilgili araştırmaları içerir), (7) Bilgi ve iletişim teknolojileri okuryazarlığı

Dünyaya Entegrasyon: (8) Vatandaşlık (Yerel ve küresel), (9) Yaşam ve kariyer, (10) Kişisel ve sosyal sorumluluk (buna kültürel farkındalık ve yeterlilikler de dâhildir).

Benzer şekilde UNESCO, yeterlilik çerçeveleri kavramının ötesine geçen 21. Yüzyılda Öğrenmeye Yönelik Kılavuz İlkeleri 2014 yılında yayımlamıştır. Bu yol gösterici ilkeler bir dizi yeterlilik ve tutumları ele almaktadır: akademik dürüstlük, bilgi okuryazarlığı, eleştirel düşünme, yaratıcılık, STEM (bilim, teknoloji, mühendislik ve matematik) öğrenme, kavram odaklı öğrenme, sağlık ve farkındalık, öğrenme desteği, değerlendirme. Yol gösterici ilkelerin odağı, yeterliliğin tanımına değil, çocuklara ve gençlere bu yeterlilikleri edinmelerinde yardımcı olma yaklaşımına dayanmaktadır. 
21. yüzyıl becerileri literatürde farklı şekillerde tanımlansa da tanımların hepsinde genellikle öğrencilerin bilgiyle neler yapabileceğine ve öğrendiklerini gerçek bağlamda nasıl uygulayacaklarına vurgu yapılmaktadır. 21. yüzyıl becerilerinin özünde güçlü iletişim ve iş birliği becerileri, teknolojide uzmanlık, yenilikçi ve yaratıcı düşünme becerileri ve problem çözme becerileri vardır. Bu açıdan baktığımızda 21. yüzyıl becerileri gerçekten yeni mi sorusunu gündeme getirmektedir (Larson ve Miller, 2011). Silva' ya göre (2009, s. 631) 21. yüzyıl becerileri yeni değildir, ancak bugünün çalışanlarının birden fazla kaynaktan bilgiyi bulup analiz edebilmeleri ve bu bilgileri kararlar almak ve yeni fikirler oluşturmak için kullanabilmeleri gerektiği için "yeni önemlidir". Tarihsel olarak, bu öğrenme ve inovasyon becerilerine duyulan ihtiyaç, ilk profesyonel öğretmenler olan Socrates ve Sofistlere kadar izlenebilir (Larson ve Miller, 2011).

21. yüzyıl beceri hareketinin destekçileri ve savunucuları, 21. yüzyılda öğrencilerin ve toplumun sosyal ve ekonomik ihtiyaçlarına cevap vermek için okullarda ve eğitimde reform ihtiyacının olduğunu savunurlar (Larson ve Miller, 2011). Öğretmenlerin, öğrencileri 21. yüzyıl iş dünyasına daha iyi hazırlamaları beklenmektedir. 21. yüzyılın işgücüne hazır olma durumu, öğrencilerin problem çözme, değerlendirme, akıl yürütme, karar verme ve dijital teknolojiyi kullanma becerisi gibi becerileri kullanarak karmaşık ve zorlu görevlere uygulayabilmesini gerektirir. 21. yüzyıl becerilerinin öğrenilmesinin veya öğretilmesinin değerlendirilmesi ile ilgili çalışmalar genellikle bu becerilerin bir alt kümesini incelemeye odaklanmıştır. Ancak, 21. yüzyılın tüm beceri setinin sistematik bir değerlendirmesini yapmamışlardır (Jia ve diğerleri, 2016). Bu çalışma öğretmen adaylarının 21. yüzyıl becerilerindeki yeterliliklerine ilişkin algılarını analiz etmektedir. Böyle bir çalışmanın, 21. yüzyıl beceri öğretiminin geliştirilmesi için hizmet öncesi öğretmen eğitiminde ihtiyaç duyulan alanların belirlenmesine hizmet edebileceğine inanılmaktadır. Başka bir deyişle bu çalışma sosyal bilgiler dersi öğretim programının belirtilen 21 yüzyıl becerilerini kazandırmada güçlü ve zayıf yönlerinin belirlenmesinde faydalı olabilir. Bu tür çalışmalar aynı zamanda mevcut ve gelecekteki öğretmenlerin 21. yüzyıl becerilerinin neler olduğunu öğrenme ve güçlendirilmesi gereken alanları belirlemelerine yönelik bir kendini yansıtma veya değerlendirme aracı olarak da kullanılabilir. Ayrıca bu çalışma öğretmen eğitimcilerinin 21. yüzyıl becerilerini anlamasına ve öğretmen adaylarına ne öğrettiği kadar, onları nasıl eğitip hazırladığını görmesine de yardımcı olabilir. Bu amaçlarla çalışmada aşağıdaki araştırma sorularına yanıt aranmıştır. 
1. Sosyal bilgiler öğretmen adaylarının 21. yüzyıl becerilerine sahip olma düzeyleri nedir?

2. Sosyal bilgiler öğretmen adaylarının cinsiyetlerine göre 21. yüzyıl beceri ortalama puanları arasında anlamlı bir fark var mıdır?

3. Sosyal bilgiler öğretmen adaylarının sınıf düzeyine göre 21. yüzyıl beceri ortalama puanları arasında anlamlı bir fark var mıdır?

4. Öğretmen eğitimi sırasında bu becerilerin öğretimindeki en önemli engeller nelerdir?

5. Üniversite ve öğretmen eğitimcileri bu becerileri geliştirmede nasıl yardımcı olabilir?

\section{Yöntem}

\section{Çalışmanın Yöntemi}

Yapılan bu çalışmada mevcut sosyal bilgiler öğretmenliği lisans programının 21. yüzyıl becerilerini kazandırma konusunda ne kadar yeterli olduğunu, öğretmen adaylarının bakış açısıyla ortaya koymak amacıyla açımlayıcı (explanatory) karma yöntem kullanılmıştır. Creswell'e (2008) göre karma yöntem araştırmalarının temel varsayımı, nitel ve nicel araştırma yöntemlerinin birlikte veya harmanlanarak kullanılmasının araştırma probleminin ve sorularının bu yöntemlerin ayrı kullanılmasından daha iyi anlaşılmasını sağlamasıdır. Açımlayıcı (explanatory) karma yöntemde çalışma iki farklı araştırma projesi halinde yürütülür. Önce nicel araştırma yapılır, sonra nitel araştırma bunun üzerine oturtularak planlanır (Creswell, 2008).

$\mathrm{Bu}$ çalışmada karma yöntemin seçilmesinin temel nedeni, nitel ve nicel yöntemlerin birlikte kullanılmasıyla araştırma probleminin, her bir yöntemin tek başına yapacağından daha iyi anlaşılmasını sağlamaktır. Ayrıca çalışmada nitel araştırma yöntemi ile toplanan veriler, ilk aşamadaki nicel sonuçları doğrulanmak ve öğretmen adaylarının deneyimlediği problemlerin nedenlerini ve çözüm önerilerini derinlemesine keşfetmeye yardımcı olmuştur. Bu çalışmada 21. yüzyıl becerileri öğretmen adayı ölçeği ve yarı yapılandırılmış görüşme formu veri toplama araçları olarak kullanılmıştır. Araştırma süresince önce nicel daha sonra nitel veriler toplanıp analiz edilmiştir. Her iki veri setinin analiz sonuçları karşılaştırılıp birbirleriyle uyumlu olup olmadığına bakılarak yorumlanmıştır. 


\section{Nicel Boyut}

Çalışmanın nicel boyutunda tarama yöntemi kullanılmıştır. Tarama yöntemi, bir konu ya da durumla ilgili araştırmaya katılan katılımcıların düzey, görüş, tutum, ilgi ve yeterliklerini ortaya çıkartmak için yapılan araştırmalardır (Büyüközürk, Kılıç-Çakmak, Akgün, Karadeniz ve Demirel; 2008).

\section{Evren-Örneklem}

$\mathrm{Bu}$ çalışmanın evrenini sosyal bilgiler öğretmenliği lisans programında okuyan öğretmen adayları oluşturmaktadır. Çalışmanın örneklemini ise, orta ölçekli bir devlet üniversitesinde okuyan toplam 335 sosyal bilgiler öğretmen adayı oluşturmaktadır. Bu öğretmen adaylarının 194'ü kadın $(\% 57,9), 141$ ’i ise erkektir $(\% 42,1)$. 21. yüzyıl becerilerini kazandırma konusunda programın ne kadar yeterli olduğunu ve sınıflar arasında bir fark olup olmadığını ortaya koyabilmek için çalışmada olasılığa dayalı örneklem çeşitlerinden biri olan oransız küme örnekleme kullanılmıştır. Küme örnekleme, evrendeki bütün kümelerin bütün elemanlarıyla birlikte eşit seçilme şansına sahip oldukları durumda yapılan bir örnekleme çeşididir (Karasar, 2018, s. 153).

\section{Nicel veri toplama aracı}

Bu çalışmada 21. yüzyıl becerilerinin kavramsallaştırılması amacıyla Niemi, Pehkonen, Niu, Teng ve Harju (2018) tarafindan geliştirilen ölçme aracı kullanılmıştır. Ölçme aracı araştırmacı tarafından Türkçeye çevrildikten sonra iki alan eğitimcisi ve bir İngilizce eğitimcisi tarafından incelenmiştir. Alınan dönütler doğrultusunda üzerinde gerekli düzeltmeler yapılarak ölçeğe son hali verilmiştir.

Yapı geçerliği çalışması kapsamında yapılan DFA analizi sonucunda ölçeğin orijinal formunda yer alan maddeler ile maddelerin ölçtüğü yapı arasındaki standartlaştırılmış faktör yükleri $t$ değerlerine göre istatistiksel olarak anlamlı bulunmuştur. 21. yüzyıl becerileri ölçeğine ilişkin DFA t değerleri 9.82 ve 12.12 arasında değişmektedir (Ek 1). Dolayısıyla herhangi bir maddenin ölçekten çıkarılmasına gerek duyulmamıştır (Seçer, 2015).

DFA ile ilgili ikinci incelenen durum maddelerin faktör yük değerleridir. Tüm faktör yüklerinin 0.30'un üzerinde olduğu Ek 2'de görülmektedir (Seçer, 2015) (Sadece yerel bağlantılar faktörü altındaki son madde 0.29 değerindedir). Bu nedenle, ölçekte yer alan maddelerin 21. yüzyıl becerileri ölçeğinin yapısını ölçtüğü söylenebilir. Uygulanan DFA sonucunda ki-kare $(\chi 2)$ uyumu ve yaklaşık hataların ortalama karekökü (Root Mean Square 
Error of Approximation, RMSEA) değerleri incelenmiştir. Ki-kare uyum testinde kikare/serbestlik derecesi değerinin üçten (3) küçük elde edilmesi iyi uyumun göstergesi olarak değerlendirilmiştir (Schumacker ve Lomax, 2010). RMSEA $\leq 0.05$ (SchermellehEngel, Moosbrugger ve Müller, 2003) mükemmel uyum olarak kabul edilmiştir. Elde edilen bulgular Tablo 1'de sunulmuştur.

Tablo 1. 21. yüzyıl becerileri Ölçeğine İlişkin DFA Uyum İndeksleri

$\chi^{2 / s d} \quad$ RMSEA

\begin{tabular}{lll}
\hline Ölçek & 1.72 & .046
\end{tabular}

Örneklem büyüdükçe ki-kare analizi sonuçlarının anlamlı çıkma olasılığı artmaktadır. Yapılan birçok DFA'da örneklemin büyük olması nedeniyle $\mathrm{p}$ değerinin anlamlı olması normal olup, bu durum çalışmaların çoğunda tolere edilmektedir (Büyüköztürk, Akgün, Özkahveci ve Demirel, 2004). Bu bulgulardan hareketle faktörlerin veri tarafından doğrulandığı söylenebilir.

Çalışmada güvenirlik çalışması yapılmıştır. Güvenirlik; bir ölçme aracının duyarlı, tutarlı ve tesadüfi hatadan arınık ölçümler verme derecesi olarak tanımlanabilir (Fraenkel ve Wallen, 1996). Bu araştırmada ölçeğin güvenirliği Cronbach Alpha ile hesaplanmıştır. 21. yüzyıl beceri ölçeğinden elde edilen toplam puanların ve alt faktörlere ait maddelerden alınan toplam puanların güvenirlikleri hesaplanmış ve Tablo 2'de sunulmuştur.

Tablo 2. Cronbach's Alpha Güvenirlik Katsayıları

\begin{tabular}{lll}
\hline Ölçek ve alt faktörler & Cronbach's Alpha & Madde Sayısı \\
\hline Toplam Ölçek & 0,96 & 58 \\
Dijital Ortamlarda Öğretim & 0,91 & 8 \\
Eleştirel Düşünme & 0,84 & 6 \\
İletişim Becerileri & 0,87 & 7 \\
İş Birliği Becerileri & 0,89 & 6 \\
Küresel Bağlantılar & 0,88 & 6 \\
Öz Düzenleme & 0,87 & 7 \\
Teknoloji & 0,90 & 8 \\
Yaratıcılık & 0,85 & 5 \\
Yerel Bağlantılar & 0,88 & 5 \\
\hline
\end{tabular}


Güvenirlik için Cronbach alfa kat sayısı ,7 ve ,7'den büyük olmalıdır (Palant, 2017). Tablo 2'de görüldüğü gibi ölçekten alınan toplam puanın ve alt faktörlere ait madde puanlarının güvenirlikleri ,7 üzerinde bulunmuştur. Bu bağlamda toplam puan ve alt faktörlere ait madde puanlarının tesadüfi hatalardan arınık olma dereceleri ve katılımcıların bu ölçekten aldıkları puanların tutarlı olma derecelerinin yeterli düzeyde olduğu söylenebilir.

\section{Veri toplama süreci}

Veriler araştırmacı tarafından elektronik ortamda toplanmıştır. Sosyal bilgiler öğretmen adayları öncelikle ölçek ve çalışma hakkında bilgilendirilmişlerdir daha sonra ölçeğin web adresi öğretmen adaylarıyla paylaşılmıştır. Veriler 2018-2019 ĕgitim öğretim yıllarında toplanmıştır.

\section{Verilerin analizi}

Kullanılan ölçek 5'li likert (Çok yetersiz, Yetersiz, Orta, İyi, Çok iyi) şeklinde ve 58 maddeden oluşmaktadır. Çalışmaya katılan katılımcılar ölçekten en fazla 290 puan en az ise 58 puan alabilmektedirler. Katılımcıların alabilecekleri en fazla puandan en az puan çıkartılarak 5'e (5'li likert olduğu için) bölünmüştür. Sonuç katılımcıların alabilecekleri en az puana eklenerek katılımcıların mevcut sosyal bilgiler öğretmenliği lisans programının 21. yüzyıl becerilerini kazandırma konusunda yeterlilik düzey aralıkları belirlenmiştir. Yapılan bu çalışmada ayrıca 21. yüzyıl becerileri faktörlere ayrılarak incelenmiştir. 21. yüzyıl becerileri; eleştirel düşünme, iş birliği, iletişim, yaratıcılık ve yenilikçilik, öz düzenleme, küresel bağlantılar, yerel bağlantılar, teknolojiyi öğrenme için bir araç olarak kullanma ve dijital ortamlarda öğretim becerileri olmak üzere dokuz faktöre ayrılmıştır. Her bir alt faktörün yeterlilik düzey aralıkları belirlenmiştir. Katılımcıların almış oldukları toplam puanlar hesaplanmıştır. Ayrıca yapılacak analizlere karar vermek amacıyla normallik testi yapılmış ve şu sonuçlar elde edilmiştir:

Tablo 3’te görüldüğü üzere 335 öğrencinin toplam ölçek ve alt faktörlerdeki beceri maddelerinden almış oldukları toplam puanların ortalama, mod ve medyan değerleri birbirine yakındır. Basıklık ve çarpıklık değerleri $+2,-2$ aralığındadır. Bu bağlamda 335 öğrencinin toplam ölçek ve her bir beceri açısından alınan toplam puanlar normal dağılım göstermektedir. $\mathrm{Bu}$ nedenle yapılan araştırmada alt problemlere cevap bulabilmek için parametrik istatistiksel teknikler olan İlişkisiz Örneklem İçin t-testi ve Tek Faktörlü Varyans 
Analizi (ANOVA) yapılmıştır. Araştırmada yapılan analizler SPSS (22) ve LISREL (8.7) ile yürütülmüştür

Tablo 3. 21. Yüzyıl becerileri toplam ölçek ve alt faktörlerden alınan toplam puanların normal dă̆llım analizi

\begin{tabular}{lllllll}
\hline & N & Ortalama & Mod & Medyan & Basıklık & Çarpıklık \\
\hline Toplam Ölçek & 335 & 216 & 205 & 218 &,- 250 &,- 066 \\
Eleştirel düşünme & 335 & 22 & 24 & 22 &, 155 &,- 380 \\
İş birliği & 335 & 23 & 23 & 24 &, 133 &,- 359 \\
İletişim becerisi & 335 & 27 & 28 & 28 &, 080 &,- 323 \\
Yaratıcılık & 335 & 19 & 20 & 19 &, 329 &,- 422 \\
Öz-düzenleme & 335 & 26 & 28 & 27 &, 884 &,- 499 \\
Küresel bağlantılar & 335 & 18 & 24 & 21 &, 131 &,- 458 \\
Yerel bağlantılar & 335 & 18 & 20 & 19 &, 384 &,- 489 \\
Teknoloji kullanımı & 335 & 30 & 32 & 31 &, 375 &,- 449 \\
Dijital ortamlarda & 335 & 30 & 32 & 30 &, 701 &,- 591 \\
öğretim becerisi & & & & & & \\
Kız & 193 & 215 & 217 & 205 &, 008 &,- 302 \\
Erkek & 137 & 219 & 220 & 236 &,- 132 &,- 271 \\
1.Sınıf & 70 & 213 & 215 & 214 &,- 302 &,- 256 \\
2.Sınıf & 64 & 210 & 171 & 205 &,- 581 &, 288 \\
3.Sınıf & 119 & 217 & 205 & 219 &, 556 &,- 330 \\
4.Sınıf & 75 & 222 & 230 & 230 &, 386 &,- 632 \\
\hline
\end{tabular}

\section{Nitel Boyut}

Nitel veri toplama aracı ve verilerin analizi

Açımlayıcı karma yöntem araştırması olarak desenlenen çalışma sosyal bilgiler öğretmenliği lisans programı öğretmen adaylarının 21. yüzyıl becerilerine ulaşmalarına ne kadar yardımcı olduğuna ilişkin algılarının belirlenmesi açısından bir olgubilim araştırmasıdır. Başka bir deyişle çalışmanın nitel boyutunda öğretmen adaylarının bu konudaki deneyimlerine ilişkin görüşlerini ortaya koymak için nitel araştırma yöntemlerinden biri olan olgubilim yönteminden yararlanılmıştır. Burada veri kaynağı olan sosyal bilgiler öğretmen adaylarının 
eğitim fakültesindeki deneyimlerinden yola çıkarak bu konudaki algıları anlaşılmaya çalışılmıştır.

Araştırmanın nitel boyutunda, araştırmacı tarafından geliştirilen yarı yapılandırılmış görüşme formu kullanılmıştır. Yarı yapılandırılmış görüşme formunun hazırlanması aşamasında ilgili literatürün taranmasıyla elde edilen kuramsal bilgiler ve uzman görüşleri esas alınmıştır. Hazırlanan yarı yapılandırılmış görüşme formu sosyal bilgiler eğitimi alanında uzman iki öğretim üyesi tarafından incelenmiş ve gelen öneriler doğrultusunda yeniden düzenlenmiş ve pilot uygulamalar sonrasında son halini almıştır. Araştırma verileri, dönemin son haftası odak grup görüşme tekniği ile toplanmıştır. Yarı yapılandırılmış görüşmeye, ölçeği yanıtlayan öğretmen adayları içinden 11 (6 Erkek, 5 Kadın), 4. sınıf sosyal bilgiler öğretmen adayı katılmıştır. Görüşmeye katılan öğretmen adayları gönüllülük esasına dayanarak belirlenmiştir ancak tüm lisans programını değerlendirebilmeleri için 4. Sınıf öğretmen adayları tercih edilmiştir. Görüşme 45-50 dakika sürmüştür ve ses kayıt cihazı ile kaydedilmiştir. Daha sonra ses kaydı Word'e aktarılmış ve içerik analizi yapılmıştır. Çalışmada kullanılan görüşme soruları şunlardır:

1. Sosyal Bilgiler Öğretmenliği lisans programı, 21. yüzyıl becerilerini kazanmaları için öğretmen adaylarına nasıl rehberlik etmektedir?

2. En güçlü olduğunuzu düşündüğünüz beceriler nelerdir? Neden?

3. En zayıf olduğunuzu düşündüğünüz beceriler nelerdir? Neden?

4. Öğretmen eğitimi sırasında bu becerileri öğrenmede en önemli engeller nelerdir?

5. Daha ne tür beceriler geliştirmek istersiniz?

6. Üniversite ya da öğretim üyeleri bu becerileri geliştirmede size nasıl yardımc1 olabilir ve destekleyebilirler?

\section{Nitel verilerin geçerlik ve güvenirliği}

Geçerlik ve güvenirlik sağlanması doğrultusunda veriler iki farklı araştırmacı tarafından değerlendirilmiştir. Yarı yapılandırılmış görüşmelerden elde edilen verilerin incelenmesi sonucunda, veriler uygun kategorilere yerleştirilmiştir. Kategoriler birbiriyle benzerlik ve farklılıkları doğrultusunda tekrar incelenmiştir. Üzerine hemfikir ve ayrı görüş olarak ortaya çıkan kategoriler tespit edilerek Miles ve Huberman (1994, s. 64) tarafından geliştirilen “Güvenirlik = (görüş birliği/görüş birliği + görüş ayrılığı $)$ x 100” formülü kullanılmıştır. Araştırmacılar arasındaki uyum \%91 olarak tespit edilmiştir. 


\section{Bulgular}

\section{Birinci Alt Probleme Ait Bulgular}

"Sosyal bilgiler öğretmen adaylarının 21. yüzyıl becerilerine sahip olma düzeyleri nedir?" sorusuna cevap bulmak için öncelikle sosyal bilgiler öğretmenliği lisans programının 21 . yüzyıl becerilerini kazandırma konusunda yeterlilik düzey aralıkları belirlenmiştir. Toplam puan düzey aralıklarına göre katılımcıların dağılımı Tablo 4'te verilmiştir.

Tablo 4. 21. Yüzyıl becerileri toplam puan düzey aralıklarına göre katılımcıların dağılımı

\begin{tabular}{llll}
\hline Düzey & Aralık & Frekans & Yüzde \\
\hline Çok yetersiz & $58-104$ & - & - \\
Yetersiz & $105-151$ & 5 & 1,5 \\
Orta & $152-198$ & 84 & 25,1 \\
İyi & $199-245$ & 194 & 57,9 \\
Çok iyi & $246-290$ & 47 & 14,0 \\
\hline
\end{tabular}

Tablo 4'te görüldüğü gibi ölçekten alınan toplam puanlara göre sosyal bilgiler öğretmenliği lisans programının 21. yüzyıl becerilerini kazandırma konusunda; kötü düzeyde olduğunu belirten beş öğretmen adayı, orta düzeyde olduğunu belirten 84 öğretmen aday1, iyi düzeyde olduğunu belirten 194 öğretmen adayı ve çok iyi düzeyde olduğunu belirten 47 öğretmen adayı bulunmaktadır. Düzeylerin frekans yüzdelerine bakıldığı zaman katılımcıların \%71,9'unun sosyal bilgiler öğretmenliği lisans programının 21. Yüzyıl becerilerini kazandırma konusunda iyi ve çok iyi düzeyde olduğunu ifade ettiği görülmektedir.

Yapılan bu çalışmada ayrıca 21. yüzyıl becerileri faktörlere ayrılarak incelenmiştir. Her bir alt faktörün belirlenen düzey aralıklarına göre alt faktörlerin frekans ve yüzde değerleri Tablo 5'te verilmiştir. Tablo 5 incelendiğinde sosyal bilgiler öğretmenliği lisans programının 21. yüzyıl becerilerinden iş birliği ve iletişim becerilerini kazandırma konusunda daha iyi olduğu ancak küresel bağlantılar ve dijital ortamlarda öğretim becerisini kazandırma konusunda ise yeterli olmadığı görülmektedir. Her bir becerinin "iyi” ve "çok iyi” düzey aralıklarına göre belirlenen frekans yüzdeleri dikkate alındığında en başarılı olandan en başarısıza doğru sıralama şu şekildedir: İş birliği becerisi $(\% 73,2)$, iletişim becerisi $(\% 73,1)$, eleştirel düşünme becerisi $(\% 69,8)$, teknolojiyi öğrenme için bir araç 
F.Bozkurt/ Pamukkale Üniversitesi Eğitim Fakültesi Dergisi, 51, 34-64, 2021

olarak kullanma becerisi $(\% 66,6)$, yaratıc1lık ve yenilikçilik $(\% 66,3)$, öz düzenleme becerisi $(\% 66,2)$, yerel bağlantılar $(\% 62,4)$, dijital ortamlarda öğretim becerileri $(\% 59,7)$ ve küresel bağlantılar $(\% 54,0)$.

Tablo 5. 21. Yüzyıl becerileri alt faktörlerin düzey aralıklarına göre belirlenen frekans dĕgerleri

\begin{tabular}{|c|c|c|c|c|c|c|c|c|c|c|}
\hline \multirow[t]{3}{*}{ Alt faktörler } & \multirow{2}{*}{\multicolumn{2}{|c|}{$\begin{array}{l}\text { Çok } \\
\text { Yetersiz }\end{array}$}} & \multirow{2}{*}{\multicolumn{2}{|c|}{ Yetersiz }} & \multirow{2}{*}{\multicolumn{2}{|c|}{ Orta }} & \multirow{2}{*}{\multicolumn{2}{|c|}{ İyi }} & \multirow{2}{*}{\multicolumn{2}{|c|}{ Çok İyi }} \\
\hline & & & & & & & & & & \\
\hline & $\mathbf{f}$ & $\%$ & $\mathbf{f}$ & $\%$ & $\mathbf{f}$ & $\%$ & $\mathbf{f}$ & $\%$ & $\mathbf{f}$ & $\%$ \\
\hline Eleştirel düşünme & - & - & 15 & 4,5 & 85 & 25,4 & 190 & 56,7 & 44 & 13,1 \\
\hline İş birliği & 2 & 0,6 & 11 & 3,3 & 77 & 23,0 & 160 & 47,8 & 85 & 25,4 \\
\hline İletişim becerisi & - & - & 13 & 3,9 & 72 & 21,5 & 174 & 51,9 & 71 & 21,2 \\
\hline $\begin{array}{l}\text { Yaratıcıllk ve } \\
\text { Yenilikçilik }\end{array}$ & 2 & 0,6 & 17 & 5,1 & 94 & 28,1 & 160 & 47,8 & 62 & 18,5 \\
\hline Öz-düzenleme & 2 & 0,6 & 13 & 3,9 & 98 & 29,3 & 185 & 55,2 & 37 & 11,0 \\
\hline $\begin{array}{l}\text { Küresel } \\
\text { bağlantılar }\end{array}$ & 11 & 3,3 & 42 & 12,5 & 101 & 30,1 & 138 & 41,2 & 43 & 12,8 \\
\hline Yerel bağlantılar & 6 & 1,8 & 31 & 9,3 & 89 & 26,6 & 151 & 45,1 & 58 & 17,3 \\
\hline $\begin{array}{l}\text { Teknoloji } \\
\text { kullanımı }\end{array}$ & 3 & 0,9 & 17 & 5,1 & 92 & 27,5 & 158 & 47,2 & 65 & 19,4 \\
\hline $\begin{array}{l}\text { Dijital ortamlarda } \\
\text { öğretim }\end{array}$ & 8 & 2,4 & 22 & 6,6 & 105 & 31,3 & 143 & 42,7 & 57 & 17,0 \\
\hline
\end{tabular}

\section{İkinci Alt Probleme Ait Bulgular}

“Öğretmen adaylarının cinsiyetlerine göre 21. yüzyıl beceri ortalama puanları arasında anlamlı bir fark var mıdır?” alt problemini çözümlemek amacıyla ilişkisiz örneklem için ttesti yapılmıştır. Grupların varyanslarının eşit olup olmadığını belirlemek amacı ile Levene testi uygulanmış kız ve erkek öğrencilerin verdikleri cevapların varyanslarının eşit olduğu sonucuna ulaşılmıştır $(\mathrm{F}=, 760 ; \mathrm{p}>0.01)$. Bu duruma uygun olarak yapılan İlişkisiz Örneklem 
için t-test analizi sonunda farklı cinsiyetteki öğrencilerin 21. yüzyıl beceri toplam puanları arasında 0.05 manidarlık düzeyinde anlamlı bir fark belirlenmemiştir $(\mathrm{t}=-1,208, \mathrm{p}=, 228)$. Elde edilen bulgular aşağıdaki Tablo 6'da verilmiştir

Tablo 6. Kadın ve erkek katılımcılar için İlişkisiz Örneklem t-testi

\begin{tabular}{|c|c|c|c|c|c|c|}
\hline & $\mathbf{N}$ & $\mathbf{X}$ & S.S & $\mathbf{t}$ & df & p \\
\hline $\mathrm{K}_{1 \mathrm{Z}}$ & 193 & 214,6 & 29,5 & \multirow{2}{*}{$-1,208$} & \multirow{2}{*}{328} & \multirow{2}{*}{,228 } \\
\hline Erkek & 137 & 218,5 & 27,7 & & & \\
\hline
\end{tabular}

İlişkisiz örneklem t-testi toplam puan haricinde 21. yüzyıl becerileri alt faktörler de incelenmiştir (Tablo 7).

Tablo 7. Kız ve erkek katılımcılar için İlişkisiz Örneklem t-testi

\begin{tabular}{|c|c|c|c|c|c|c|c|c|c|}
\hline & Leve & ne's & & & & & & & \\
\hline & Te & & Cinsiyet & $\mathbf{N}$ & $\mathbf{X}$ & S.S & $\mathbf{t}$ & df & $\mathbf{p}$ \\
\hline & $\mathbf{F}$ & Sig. & & & & & & & \\
\hline Elestirel düsünme & 100 & 752 & $\mathrm{~K} 1 \mathrm{z}$ & 194 & 22,06 & 3,42 & 256 & 332 & 798 \\
\hline 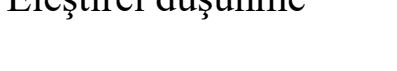 & & & Erkek & 140 & 21,96 & 3,44 & & & \\
\hline İs birliăji becerileri & 319 & 573 & $\mathrm{~K}_{1 \mathrm{z}}$ & 194 & 23,31 & 4,09 & 2,183 & 333 & .030 \\
\hline 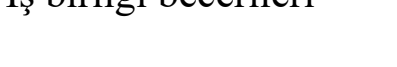 & & & Erkek & 141 & 22,34 & 3,94 & & & \\
\hline íl ticim honorilari & 102 & 148 & $\mathrm{~K} 1 \mathrm{z}$ & 193 & 27,17 & 4,63 & 647 & 220 & 521 \\
\hline 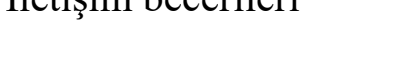 & 2,100 &, 140 & Erkek & 137 & 26,86 & 4,01 & , 042 & 320 &, 521 \\
\hline Yaratıcılık & 3701 & 052 & $\mathrm{~K} 1 \mathrm{z}$ & 194 & 18,69 & 3,46 & 060 & 222 & \\
\hline yenilikçilik & 5,191 & , & Erkek & 141 & 18,67 & 3,09 & , & 333 & ,952 \\
\hline Öz düzenleme & 050 & 822 & $\mathrm{~K}_{1 \mathrm{Z}}$ & 194 & 25,98 & 4,26 & 496 & 333 & 620 \\
\hline & & & Erkek & 141 & 25,75 & 4,42 & & & \\
\hline Küresel hă̆lantılar & 928 & 336 & $\mathrm{~K} 1 \mathrm{z}$ & 194 & 20,11 & 4,96 & - & 333 & 023 \\
\hline & & & Erkek & 141 & 21,34 & 4,72 & 2,283 & & \\
\hline Yerel haŏlantılar & 052 & 820 & $\mathrm{~K} 1 \mathrm{z}$ & 194 & 18,09 & 3,73 & -788 & 333 & 431 \\
\hline & & & Erkek & 141 & 18,43 & 3,97 & & & \\
\hline Teknoloii kullanımı & 009 & 023 & $\mathrm{~K} 1 \mathrm{z}$ & 194 & 30,38 & 5,70 & -116 & 333 & 908 \\
\hline 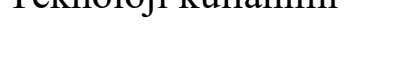 & , & & Erkek & 141 & 30,46 & 5,88 & , & ( & (1) \\
\hline Dijital ortamlarda & 015 & 903 & $\mathrm{~K} 1 \mathrm{Z}$ & 194 & 28,64 & 6,10 & - & 333 & 2 \\
\hline öğretim & & & Erkek & 141 & 30,83 & 6,38 & 3,174 & & \\
\hline
\end{tabular}


F.Bozkurt/ Pamukkale Üniversitesi Eğitim Fakültesi Dergisi, 51, 34-64, 2021

Tablo 7'de görüldüğü gibi 21. yüzyıl becerileri alt faktörlerinin her birinde kız ve erkeklerin varyanslarının eşit olduğu tespit edilmiştir. İlişkisiz Örneklem t-test analizi sonunda cinsiyet açısından iş birliği becerileri puanlarında kız öğretmen adayları, küresel bağlantılar ve dijital ortamda öğretim becerilerinde ise erkek öğretmen adayları lehine anlamlı fark bulunmuştur.

\section{Üçüncü Alt Probleme Ait Bulgular}

“Öğretmen adaylarının sınıf düzeyine göre 21. yüzyıl beceri ortalama puanları arasında anlamlı bir fark var mıdır?" alt problemini çözümlemek amacıyla Tek Faktörlü Varyans Analizi (ANOVA) yapılmıştır. Levene's testinden elde edilen sonuçlar tüm sınıflar arasında toplam puan varyanslarının eşit olarak dağıldığını göstermektedir (Tablo 8). Varyanslar eşit olduğu için post hoc analizinde LSD testine göre sinıflar arasında fark olup olmadığı incelenmiştir.

Tablo 8. Faktörler Açısından ANOVA Levene istatistik Değerleri

\begin{tabular}{lcccc}
\hline & Levene Statistic & df1 & df2 & Sig. \\
\hline Eleştirel düşünme & 1,184 & 3 & 330 &, 316 \\
\cline { 2 - 5 } İş birliği becerileri &, 391 & 3 & 331 &, 759 \\
\cline { 2 - 5 } İletişim becerileri &, 534 & 3 & 326 &, 659 \\
\cline { 2 - 5 } Yaratıcılık ve yenilikçilik &, 102 & 3 & 331 &, 959 \\
\cline { 2 - 5 } Öz düzenleme &, 912 & 3 & 331 &, 435 \\
Küresel bağlantılar & 2,096 & 3 & 331 &, 101 \\
Yerel bağlantılar &, 483 & 3 & 331 &, 694 \\
Teknolojiyi kullanma &, 825 & 3 & 331 &, 231 \\
\cline { 2 - 5 } Dijital ortamlarda öğretim & 1,440 & 3 & 326 &, 850 \\
Toplam Ölçek &, 266 & 381
\end{tabular}

Tablo 8'e bakıldığında I., II., III. ve IV. Sınıflarında okuyan sosyal bilgiler öğretmen adaylarının 21. yüzyıl becerilerine ait toplam puanları açısından sınıflar arasında anlamlı bir fark gözlemlenmediği görülmektedir. Ancak öğretmen adaylarının 21. yüzyıl becerilerine ait alt faktörlerden almış oldukları toplam puanların beceriler açısından sadece dijital ortamlarda öğretim becerileri ortalama puanları açısından sınıflar arasında fark 
gözlemlendiği görülmektedir. 4. Sınıfların dijital ortamlarda öğretim ortalama puanlarının 1, 2 ve 3. Sınıflara göre anlamlı olarak daha iyi olduğu tespit edilmiştir (Tablo 9).

Tablo 9. ANOVA sonuçlarına göre faktörlerin sınıf bazında değerleri

\begin{tabular}{|c|c|c|c|c|c|c|}
\hline & $\begin{array}{l}\text { Varyansın } \\
\text { Kaynağı }\end{array}$ & $\begin{array}{l}\text { Kareler } \\
\text { Toplamı }\end{array}$ & df & $\begin{array}{l}\text { Kareler } \\
\text { Ortalaması }\end{array}$ & $\mathbf{F}$ & Sig. \\
\hline \multirow{3}{*}{$\begin{array}{l}\text { Eleştirel } \\
\text { düşünme }\end{array}$} & $\begin{array}{c}\text { Gruplar } \\
\text { arası }\end{array}$ & 13,397 & 3 & 4,466 & \multirow[t]{3}{*}{,377 } & \multirow[t]{3}{*}{,769 } \\
\hline & Grup içi & 3905,456 & 330 & 11,835 & & \\
\hline & Toplam & 3918,853 & 333 & & & \\
\hline \multirow{3}{*}{$\begin{array}{l}\text { İş birliği } \\
\text { becerileri }\end{array}$} & $\begin{array}{c}\text { Gruplar } \\
\text { aras1 }\end{array}$ & 24,662 & 3 & 8,221 & \multirow[t]{3}{*}{,498 } & \multirow[t]{3}{*}{,684 } \\
\hline & Grup içi & 5464,281 & 331 & 16,508 & & \\
\hline & Toplam & 5488,943 & 334 & & & \\
\hline \multirow{3}{*}{$\begin{array}{l}\text { İletişim } \\
\text { becerileri }\end{array}$} & $\begin{array}{c}\text { Gruplar } \\
\text { aras1 }\end{array}$ & 125,698 & 3 & 41,899 & \multirow[t]{3}{*}{2,204} & \multirow[t]{3}{*}{,088 } \\
\hline & Grup içi & 6198,620 & 326 & 19,014 & & \\
\hline & Toplam & 6324,318 & 329 & & & \\
\hline \multirow{3}{*}{ Yaratıcılık } & $\begin{array}{c}\text { Gruplar } \\
\text { arası }\end{array}$ & 23,337 & 3 & 7,779 & \multirow[t]{3}{*}{, 707} & \multirow[t]{3}{*}{, 548} \\
\hline & Grup içi & 3640,753 & 331 & 10,999 & & \\
\hline & Toplam & 3664,090 & 334 & & & \\
\hline \multirow{3}{*}{ Öz düzenleme } & $\begin{array}{c}\text { Gruplar } \\
\text { aras1 }\end{array}$ & 36,137 & 3 & 12,046 & \multirow[t]{3}{*}{,642 } & \multirow[t]{3}{*}{, 589} \\
\hline & Grup içi & 6214,777 & 331 & 18,776 & & \\
\hline & Toplam & 6250,913 & 334 & & & \\
\hline \multirow{3}{*}{$\begin{array}{c}\text { Küresel } \\
\text { bağlantılar }\end{array}$} & $\begin{array}{c}\text { Gruplar } \\
\text { aras1 }\end{array}$ & 84,372 & 3 & 28,124 & \multirow[t]{3}{*}{1,175} & \multirow[t]{3}{*}{,319 } \\
\hline & Grup içi & 7921,199 & 331 & 23,931 & & \\
\hline & Toplam & 8005,570 & 334 & & & \\
\hline \multirow[t]{2}{*}{ Yerel bağlantılar } & $\begin{array}{l}\text { Gruplar } \\
\text { aras1 }\end{array}$ & 40,240 & 3 & 13,413 & \multirow[t]{2}{*}{,910 } & \multirow[t]{2}{*}{,436 } \\
\hline & Grup içi & 4876,656 & 331 & 14,733 & & \\
\hline
\end{tabular}


F.Bozkurt/ Pamukkale Üniversitesi Eğitim Fakültesi Dergisi, 51, 34-64, 2021

\begin{tabular}{|c|c|c|c|c|c|c|}
\hline & Toplam & 4916,896 & 334 & & & \\
\hline \multirow{3}{*}{ Teknoloji } & $\begin{array}{l}\text { Gruplar } \\
\text { arası }\end{array}$ & 256,111 & 3 & 85,370 & \multirow[t]{3}{*}{2,598} & \multirow[t]{3}{*}{, 052} \\
\hline & Grup içi & 10877,382 & 331 & 32,862 & & \\
\hline & Toplam & 11133,493 & 334 & & & \\
\hline \multirow{3}{*}{ Dijital ortam } & $\begin{array}{l}\text { Gruplar } \\
\text { arası }\end{array}$ & 1069,251 & 3 & 356,417 & \multirow[t]{3}{*}{9,644} & \multirow[t]{3}{*}{,000 } \\
\hline & Grup içi & 12232,851 & 331 & 36,957 & & \\
\hline & Toplam & 13302,101 & 334 & & & \\
\hline \multirow{3}{*}{ Toplam Ölçek } & $\begin{array}{l}\text { Gruplar } \\
\text { aras1 }\end{array}$ & 5779,335 & 3 & 1926,445 & \multirow{3}{*}{2,352} & \multirow{3}{*}{,072 } \\
\hline & Grup içi & 266980,753 & 326 & 818,959 & & \\
\hline & Toplam & 272760,088 & 329 & & & \\
\hline
\end{tabular}

\section{Dördüncü Alt Probleme Ait Bulgular}

Öğretmen adaylarının “Öğretmen eğitimi sırasında bu becerilerin öğretimindeki önemli engeller nelerdir?" sorusuna ilişkin görüşlerinin analizi sonucunda beş tema ortaya çıkmıştır. Öğretmen adaylarının ifadelerinden alıntılar ve temalar Tablo 10'da sunulmuştur.

Tablo 10. Öğretmen ĕgitimi sırasında bu becerilerin öğretimindeki önemli engeller

\begin{tabular}{ll}
\hline Temalar & Öğretmen adaylarının ifadeleri \\
\hline Öğretmen & Üniversitede hala öğrenci merkezli değil öğretmen merkezli bir \\
eğitimcilerinin & eğitim var. Bunun sıkıntısını yaşıyoruz o yüzden öğretim üyeleri \\
yetersizliği & rehberlik etme konusunda çok yetersiz kalıyor. \\
& Bize burada öğrenci merkezli ders işleyin diyen hocalarımız bile \\
& öğretmen merkezli ders işliyor. \\
& Derslerimiz genellikle öğretmen merkezli, öğretmen merkezli bir \\
& programda zaten yaratıcılık, yenilikçilik beklenemez. \\
& Öğretmen eğitimcisi o dönemin programı ne gerektiriyor o konu \\
& üzerinden sadece not aldırma ya da dersleri düz anlatım yöntemiyle \\
& açıkladığı için öğrencilere ne eleştirel bakış ne de yaratıcılık \\
& açısından bir şey kattığını düşünmüyorum.
\end{tabular}


Rehber

öğretmenlerin yetersizliği

Sınıf düzeni

KPSS kaygis 1
Benim 2013'te buradan mezun olan bir hocam staj rehberim, düz anlatım yöntemini kullanıyor çok şaşırdım. Sadece anlatıyor ve yazdırıyor, 2 saat boyunca yazı yazdırdığını bilirim. Öğrenci kâğıda yazdığını ezberliyor ve geçiyor, sosyal bilgileri öğrenmiyor.

Okul deneyiminde öğretmenler staj öğrencilerini bir kaçış noktası olarak görüyor ve sınıfı bize bırakıp dışarı çıkma, nefes alma firsatı olarak görüyorlar bu nedenle onların deneyimlerinden hiçbir şey kazanmiyoruz.

Staj okullarında öğretmenlerin hepsi 15-20 yıl üzeri deneyimli öğretmenler, deneyimli olmak bir avantaj ancak bu durum dezavantaja da dönüşebiliyor çünkü değişime karşı daha dirençli hale geliyorlar.

Sınıfın yapısına baktığımızda ön taraf hocaların ders anlattığı kürsü kısmı zaten öğretmen ve öğrenci arasındaki hiyerarşiyi gösteriyor.

Bizim sınıflardaki sıralar önceden hareketli sıralardı daha sonra temizlenmesi zor gerekçesiyle hepsini sabit sıralar yaptılar sınıftaki çalışma ortamını o da etkiliyor bence, çünkü öğrenciyi oraya sabitliyor.

Öğretmenlik yapabilmemiz için önümüzde geçmemiz gereken bir KPSS gerçeği var, gelecek kaygısı gelişmemizi engelliyor. Herkes sadece bölüm derslerine odaklanmış durumda.

KPSS puanına göre atama yapılıyor, öğretmen adayının gerçekten öğrenciye katabileceği becerilere bakılmıyor.

Tablo 10 incelendiğinde, çalışmaya katılan öğretmen adayları tarafından 21. yüzyıl becerilerinin kazandırılmasında en önemli engelin, öğretmen eğitimcilerinin öğrenci merkezli derslerin önemine vurgu yapmalarına rağmen kendilerinin derslerini bu şekilde modelleyememesi olduğu belirtilmiştir. Bunun yanı sıra öğretmenlik uygulaması derslerindeki rehber öğretmenlerin bu becerilerin kazandırılması konusunda öğrencilere rehberlik etmede yetersiz kalması, eğitim fakültesindeki sınıfların fiziki koşullarının öğrenci 
F.Bozkurt/ Pamukkale Üniversitesi Eğitim Fakültesi Dergisi, 51, 34-64, 2021

merkezli (aktif) öğrenmeye uygun olmaması ve KPSS (Kamu Personeli Seçme Sınavı) sınavının daha çok bilişsel becerilere odaklanması nedeniyle öğrencilerin kendi profesyonel gelişimlerine odaklanamaması olarak ifade edilmiştir.

\section{Beşinci Alt Probleme Ait Bulgular}

Öğretmen adaylarının “Üniversite ve ögretmen eğitimcileri bu becerileri geliştirmede nasıl yardımcı olabilir?" sorusuna ilişkin görüşlerinin analizi sonucunda beş tema ortaya çıkmıştır. Öğretmen adaylarının ifadelerinden alıntılar ve temalar Tablo 11'de sunulmuştur.

Tablo 11. Öğretmen ĕgitiminde bu becerilerin geliştirilmesine yönelik öneriler

\begin{tabular}{ll}
\hline Temalar & Öğretmen adaylarının ifadeleri \\
\hline Öğretmen & Öncelikle bu becerilerin öğrencilere kazandırılabilmesi için \\
eğitimcisi $\quad$ model & hocalarımızın bunu kendisinin kullanması lazım. \\
olmalı & Öğretmenler gerçekten faydalı olabilecek uygulanabilecek teknikler \\
& göstermeliler \\
& Öğrencilerin öğretmenlerden daha fazla rol aldığı bir sınıf ortamı \\
& yaratılabilir
\end{tabular}

Beceri odaklı Sosyal bilgilere özgü yeni dersler açılabilir. Örneğin iletişim dersi, dersler konulmalı eleştirel düşünme dersi. İletişim dersimiz var ama her şey bilgi düzeyinde kalıyor, uygulamaya geçemiyoruz.

Sosyal katılım becerisine yönelik bir ders olabilir. Eleştirel düşünme, analiz yapabilme gibi. Beceriye yönelik dersler olmalı.

Beceri ve değer kazandırmaya dönük ders sayısının artırılmasını istiyorum

Denetim yapılmalı Üzerinde durduğunuz becerilerin hepsi teoride çok iyi ama uygulama anlamında sıkıntı çekiyoruz. Beceriler kazanılmış mı diye yeni programa uygun çağdaş testlerle test edilmeli, öğretmen adayları bunu gerçekten kavramış $\mathrm{m} 1$ test edilmelidir. Bunun denetimi yapılırsa sağlıklı olacağını düşünüyorum.

Birçok hocamız formasyon dersi alamamıştır diye düşünüyorum 
bizim bölümde. Öğretmen olmakla bitmiyor, yöntemini değiştirebilir, tekniğini değiştirebilir. Öğretmenlerin çok büyük sorumlulukları olduğunu düşünüyorum ben, denetim mekanizması olması lazım, yani kendilerini geliştirmek için sorumlulukları olması lazım.

Okul deneyimi Öğretmenlik uygulaması sadece dördüncü sınıfta yapılmamalı, daha dersleri daha fazla erken sinıflarda başlamalı olmal1 Öğretmenlik uygulaması 3 ve 2. sınıfta da olmalı, Öğretmenlik becerisi hemen bir yılda kazanılabilecek bir şey değil, deneyim yaptıkça farklı yönlerini görüyoruz. Eksiklerimizi görüp tamamlama firsatımız oluyor.

Alternatif Değerlendirme süreci tek tip olmamalı. Değerlendirme süreci daha değerlendirme tutarlı ve geçerli olmalı.

kullanılmalı

Tablo 11 incelendiğinde öğretmen adayları 21. yüzyıl becerilerinin öğretmen eğitiminde geliştirilmesinde, öğretmen eğitimcilerinin model olarak anahtar rol oynadığını belirttikleri görülmektedir. Ayrıca öğretmen adayları programa bu becerilere yönelik yeni derslerin dâhil edilmesi ve programda yer alan becerilerin uygulamadaki programda hayata geçip geçmediğinin de alternatif ölçme değerlendirme yöntemleri ile kontrol edilmesi gerektiğini vurgulamışlardır.

\section{Tartışma ve Sonuç}

Çalışmaya katılan öğretmen adaylarından elde dilen veriler, katılımcıların \%71,9'unun sosyal bilgiler öğretmenliği lisans programının 21. Yüzyıl becerilerini kazandırma konusunda iyi ve çok iyi düzeyde olduğunu ifade ettiği görülmektedir. Ayrıca çalı̧̧mada 21. yüzyıl becerileri faktörlere ayrılarak incelenmiştir. Her bir becerinin "iyi” ve "çok iyi”" düzey aralıklarına göre belirlenen frekans yüzdeleri dikkate alındığında en başarılı olandan en başarısıza doğru sıralama şu şekildedir: İş birliği becerisi $(\% 73,2)$, iletişim becerisi $(\% 73,1)$, eleştirel düşünme becerisi $(\% 69,8)$, teknolojiyi öğrenme için bir araç olarak kullanma becerisi $(\% 66,6)$, yaratıcılık ve yenilikçilik $(\% 66,3)$, öz düzenleme becerisi $(\% 66,2)$, yerel bağlantılar $(\% 62,4)$, dijital ortamlarda öğretim becerileri $(\% 59,7)$ ve küresel 
F.Bozkurt/ Pamukkale Üniversitesi Eğitim Fakültesi Dergisi, 51, 34-64, 2021

bağlantılar $(\% 54,0)$. Buna göre öğretmen adaylarından elde dilen veriler sosyal bilgiler öğretmenliği lisans programının 21. yüzyıl becerilerinden iş birliği ve iletişim becerilerini kazandırma konusunda daha iyi olduğu ancak küresel bağlantılar ve dijital ortamlarda öğretim becerisini kazandırma konusunda ise yeterli olmadığını ortaya koymuştur. Sosyal Bilgiler dersi öğretim programında yer alan öğrenme alanlarından biri olan Küresel Bağlantılar öğrenme alanında programın yeterli görülmemesi önemli bir eksikliktir. $\mathrm{Bu}$ sonuç, resmi programda küresel bağlantılar öğrenme alanının içeriği ve kapsamı küresel eğitim anlayışının genel temalarının tümünü içerecek şekilde yer almasına rağmen uygulamadaki programda yeterli olunamadığı şeklinde yorumlanabilir. Binkley ve diğerleri (2016) tarafından yürütülen çalışmada belirtildiği gibi bir programda 21. yüzyıl becerilerinin sadece tanımlandığı, bu becerilerin nasıl ve ne şekilde başarılacağına dair bir ayrıntı derinliği olmadığında bu becerilerin öğrencilerin gerçek öğrenme deneyimlerine veya yapılan değerlendirmelere yansıması mümkün değildir. Ayrıca bu 21. yüzyıl amaçlarının veya öğretilmesini gerektiren hedeflerin çok değerli değerlendirmeleri olmadan, öğrencilerdeki değişimi görmek zordur (Binkley ve diğerleri, 2016). Bu konuda Honey, küresel farkındalık da dahil olmak üzere kilit alanlarda değerlendirmelerin varlığını ve kalitesini araştıran 21. yüzyılın değerlendirmelerinin kullanımı hakkında dünya çapında bir araştırma başlatmıştır ve programda öğrencilerin küresel ve uluslararası meseleleri anlamalarını ele alan hiçbir değerlendirmenin bulunmadığını belirtmiştir (akt. Binkley ve diğerleri, 2016: 55). Ne yazık ki ülkemizde de programda ifade edilen becerilerin nasıl kazandırılacağına yönelik bir ayrıntı derinliği bulunmamakta ayrıca bu becerilerin kazanılıp kazanılmadığı da değerlendirilmemektedir. Bu nedenle bu beceriler sadece resmi programda yer almakta ve uygulamaya geçememektedir. Ayrıca çalışmanın nitel boyutunda görüldüğü gibi KPSS sınavı öğretmen adaylarının profesyonelleşme sürecinde önemli bir engel olarak yer almakta ve onları beceri gelişiminden çok bölüm derslerini ezberlemeye yöneltmektedir.

Çalışmanın bir diğer bulgusu programın öğretmen adaylarının dijital ortamlarda öğretim becerilerinin geliştirilmesinde yeterli olmadığıdır. $\mathrm{Bu}$ bulgu çalışmanın nitel boyutundan elde edilen sonuçlarla paralellik göstermektedir. Öğretmen adayları Bilgisayar I ve Bilgisayar II derslerinin yeterli olmadığını sadece bir video hazırlayarak o dönem dersten geçtiklerini ve bu derslerde öğrenilenlerin günümüz koşulları ile kıyaslandığında güncelliğini yitirdiğini belirtmişlerdir. Hatta günümüz ilköğretim öğrencilerinin kodlama dersleri aldıklarını kendilerinin ise öğrencilerin şimdiden gerisinde kaldıklarını ifade etmişlerdir. 
Günümüz toplumunda teknoloji daha yaygın hale geldikçe, öğrencilerin dijital teknolojilerde (bilgisayarlar, elektronik beyaz tahtalar, GPS vb.) uzmanlığa olan ihtiyaçları artmaktadır. Daha da önemlisi, öğrencilerin bilgileri araştırmak, düzenlemek, değerlendirmek ve iletmek için teknolojiyi kullanma yeteneklerine olan ihtiyaçtır. 21. yüzyılın öğretmenleri, öğrencilerine geleneksel dersliklerden daha karmaşık ve çeşitli öğrenme firsatları sunan, teknoloji yönünden zengin sınıflarda rehberlik edebilmelidir (Larson ve Miller, 2011). Bu açıdan bu becerilerin öğretmen eğitimi programlarında geliştirilmesi önem arz etmektedir. Bu konuda Çakır ve Güngör (2017) tarafından yürütülen çalışmanın bulguları, öğretmen adaylarının karar verme, problem çözme, teknoloji kullanımı becerilerinde sorun yaşadıklarını göstermektedir. Ayrıca mevcut ders içeriklerinin de 21 . yüzyı öğretmen yeterlikleri bakımından yeterince işlevsel olmadığı bulgusuna ulaşılmıştır.

Aktay (2016) tarafından yürütülen başka bir çalışmada da 4 farklı üniversitede 4. Sınıfta okuyan ilköğretim öğretmen adaylarının teknoloji becerileri ile ilgili özellikleri analiz edilmiştir. $\mathrm{Bu}$ anlamda araştırma için genel kabul görmüş teknoloji standartlarından ISTE Ulusal Eğitim Teknolojisi Standartları (NETS-T) ve Öğretmenler İçin Performans Göstergeleri kullanılmıştır. Sonuçlar, öğretmen adaylarının yaklaşık \%70'inden fazlasının standartların çoğunda kendilerini yeterli gördüklerini ortaya koymuştur. Ancak, çalışmaya katılan öğretmen adaylarının bazıları, dijital araçları kullanarak yerel ve küresel topluluklara katılmak, topluluk üyeleri ve ebeveynlerle iş birliği yapmak, öğrencileri ve meslektaşlarıyla işbirlikli çalışmaları modellemek gibi konularda yeterince nitelikli hissetmediklerini belirtmişlerdir.

Bu çalışmanın bulgularına paralel olarak Türkiye'de Millî Eğitim Bakanlığı (MEB) tarafından yürütülen 21. Yüzyıl Öğrenci Profili (2011) araştırması 21. yüzyıl eğitim sistemi ile ilgili bazı ipuçları vermektedir. Bu araştırmaya katılan 10912 öğretmenin çoğu bu eğitim sisteminde; öğrencilerin evrensel değerleri yeterince edinemediğini (\%66), öğrenciler arasındaki kişisel farklılıkların dikkate alınmadığını (\%75), öğrencilere eleştirel düşünmenin yeterince kazandırılmadığını (\%77), öğrencileri araştırma ve sorgulamaya sevk etmediğini (yaklaşık \%80), öğrencilere karşılaştığı problemleri kendi başına çözme becerisi (\%80) ve kendi kararlarını alabilme becerisi kazandırmadığını (\%76) belirtmişlerdir. Ayrıca çalışmaya katılan öğretmenler, eğitimin uluslararası standartlarda olmadığını (\%85) ve öğretimdeki değerler, öğretilenler ve hedefler üzerinde yeniden düşünülmesi gerektiğini $(\% 85,4)$ belirtmişlerdir (EARGED, 2011). Bu konuda Hamarat (2019), MEB'in 21. Yüzyıl Öğrenci Profili oluşturma çalışmasının betimsel düzeyde kaldığını ve durum çalışmaları ya da eylem 
araştırmalarıyla desteklenmediğini belirtmiştir. Hamarat ayrıca 2018'de güncellenen müfredatlarla öğrencilere kazandırılması hedeflenen yeterlik ve becerilerin öğretim programlarına yansıtılması için girişimde bulunulmasına rağmen bunun bütün sistemi kapsayamaması ya da yalnızca bir boyuta odaklanması nedeniyle beklenen dönüşümün gerçekleşemediğini ifade etmiştir (Hamarat, 2019).

Başka bir çalışmada Clark (2008) Partnership21 tarafindan önerilen 21. yüzy1l becerilerini temel alarak Batı Virginia'da gerçekleştirilen teknoloji entegrasyonu sürecinde öğretmenlerin durumunu değerlendirmiştir. Çalışmanın bulguları, öğretmenlerin \%50'sinden fazlasının (bilgisayar, internet, kelime işlemci programları ve e posta hizmetleri olarak sıralanan) teknolojik araçları günlük hayatlarında kullandıklarını ancak bu araçları 21. yüzyı1 içeriklerini oluşturmada kullanmadıklarını ortaya koymuştur. Öğretmenlerin bu araçları 21. yüzyıl içeriklerini oluşturmada kullanmalarını etkileyen faktörler ise araç kullanımına yönelik mesleki gelişim eksikliği, zaman yetersizliği ve kişisel ilgi olarak sıralanmıştır. Benzer şekilde Bernhardt'ın (2015) yapmış olduğu çalışmaya katılan öğretmenlerin çoğu konu alanı bilgisi, motivasyon, katılım ve yaratıcı değerlendirme stratejilerine odaklanan genel pedagojik stratejileri içeren mesleki gelişime ihtiyaç duyduklarını ifade etmişlerdir. Ayrıca teknoloji kesinlikle profesyonel gelişimin bir parçası olsa da çalışmaya katılan öğretmenlerin teknoloji kullanımın 21. yüzyıl öğrenimindeki rolü hakkında yeterli düzeyde bir anlayışa sahip olmadığ

$\mathrm{Bu}$ çalışmanın bulgularına paralel olarak Göksun (2016) öğretmen adaylarının 21. yüzyıl öğrenen ve öğreten becerileri kullanım düzeylerini analiz ettiği çalışmada, öğretmen adaylarının bilişsel becerileri yüksek düzeyde kullandıkları, bunun yanı sıra otonom becerileri, iş birliği ve esneklik becerileri gibi gerçek yaşam problemlerini çözmeye yönelik becerileri orta noktaya yakın düzeyde kullandıkları görülmüştür. Ayrıca öğretmen yetiştirme programlarındaki teknoloji bilgisine yönelik derslerin yetersiz olduğu bulgusuna ulaşılmıştır. Bu çalışmanın bulgularından farklı olarak Çoklar (2008) tarafından Türkiye'deki yedi farklı üniversitede öğrenim gören öğretmen adayları ile yürütülen çalışmada, öğretmen adaylarının eğitim teknolojileri kullanım öz-yeterlik algılarının yüksek düzeyde olduğu bulgusuna ulaşılmıştır. Şahin (2010) tarafından altı farklı üniversitedeki öğretmen adaylarıyla yürütülen çalışmada da öğretmen adaylarının yaklaşık \%60’’nın yeni binyıl öğrencisi özelliklerini gösterdiği saptanmıştır.

Gürültü, Aslan ve Alcı (2019) tarafından yürütülen çalışmada da ortaöğretimde görev yapan öğretmenlerin 21. yüzyıl öğreten becerilerine yüksek seviyede sahip olduğunu 
düşündügü bulgusuna ulaşılmıştır. Ancak literatürde öğretmenlerin bu yeni becerileri nasıl kavramsallaştırdığı ve sınıf uygulamalarında nasıl kullandıkları ile ilgili yapılan çalışmalar bazı sorunların olduğunu ortaya koymaktadır (Bernhardt, 2015). 21. yüzyıl becerilerinin öğretimi ile ilgili eleştirilerin çoğu, bu becerileri derslerde uygulamak için bir çerçevenin olmaması ve ayrıca öğretmenlerin ve öğrencilerin yıl boyunca bu beceriler üzerinden nasıl değerlendirileceklerine ilişkin belirsizliklerin olmasıyla ilgilidir (Bernhardt, 2015).

$\mathrm{Bu}$ çalışmanın diğer bir bulgusu olan öğretmen adaylarının sınıf düzeyine göre 21 . yüzyıl beceri ortalama puanları arasında anlamlı bir fark olmamasıdır. Bu bulgu oldukça düşündürücüdür. Genel olarak, araştırmanın nitel bulguları, programın bu becerileri kazandırma konusunda çok yeterli olmadığı şeklindedir. Nitel çalışmaya sadece 4. Sınıf öğrencileri dahil edilmiştir ve onların da değerlendirmeye daha eleştirel yaklaştıkları gözlemlenmiştir. Nitel bulgular, sosyal bilgiler öğretmenliği lisans programında kullanılan yöntem ve uygulamaların ders anlatımı, not alma ve ders kitaplarının kullanımına odaklandığını ortay koymuştur. Veriler, öğretim üyelerinin daha geleneksel öğretim yöntemlerini kullandıklarını göstermektedir. Bu bulgu Ananiadou ve Claro (2009) tarafından Türkiye'deki ilk ve ortaokulların öğretim programları ile ilgili yapılan çalışmanın bulguları ile paralellik göstermektedir. OECD ülkelerinde gerçekleştirilen bu çalışmada her ülkenin öğretim programında kazandırılan temel öğrenen becerileri ortaya konmuştur. Çalışmaya göre Türkiye'deki ilk ve ortaokulların öğretim programları ile öğrenenlere; eleştirel düşünme, yaratıcı düşünme, iletişim, araştırma, problem çözme, karar verme ve bilgi ve iletişim teknolojileri becerilerinin öğretim programında kazandırılması amaçlanan beceriler olarak yer aldığını ancak bu sıralanan becerilerin öğrenme süreçlerinde işe koşulmadığını ortaya koymuştur. Çalışmada özellikle bu beceri ve yetkinlikleri hedef alan değerlendirme politikaları veya öğretmen eğitimi programlarının olmadığı ifade edilmiştir. Ayrıca 21. yüzyıl becerilerinin kazandırılmasında öğrenme ortamının beceri aktarımına uygun olarak düzenlenmesi ve ölçme değerlendirme anlayışının da buna uygun olması gerekmektedir. Öğrenme ortamının rahat, esnek ve yaratıcılığı destekleyen atmosferde olması beceri temelli gelişime büyük katkı sağlayacaktır (Hamarat, 2019). Aynı zamanda tüm öğretmen ve öğretmen adaylarının değerlendirme verilerini (öğrenci portfolyolarını, test puanlarını, işbirlikli projeleri vb.) doğru bir şekilde okuma ve yorumlama ve sınıf içi uygulamaları doğru ve uygun bir şekilde farklılaştırma becerisine sahip olması önemlidir (Miller, 2009). Bu nedenle öğretmenlere ve öğretmen adaylarına becerilere yönelik ölçme ve değerlendirme konusunda farkındalık kazandırılmalı ve eğitim verilmelidir. Öğretmen 
eğitimi, yüksek kaliteli öğretimi mümkün kılmak için gerekenlerin sadece bir bileşeni olmasına rağmen, okullarda talep edilen tüm diğer reformların başarısı için ön koşuldur (Darling-Hammond, 2006). Öğretmen eğitimcilerinin bu becerileri öğrencilerine aktarmak için kendileri 21. yüzyıl becerilerinin eşzamanlı entegrasyonunun güçlü modelleri olması gerekmektedir. Bu nedenle öğretmen eğitimcileri, öğretimlerini geliştirmek ve bu teknikleri öğrencileri için modellemek için sürekli olarak yeni teknolojileri derslerine entegre etmeli ve güncel kalmalıdırlar (Urbani, Roshandel, Michaels ve Truesdell, 2017).

Cuban (1991, akt. Russell, 2010) derin öğrenme çağrısı gerektiren araştırmaların yoğunluğuna rağmen, sosyal bilgiler öğretim programına pasif öğrenmenin, gerçeklerin sondaj ve ezberlenmesinin hala hâkim olduğunu belirtmiştir. Cuban'a göre birçok sosyal bilgiler öğretmeni, ne öğretildiği kadar içeriğin nasıl öğretildiğinin de önemli olduğu fikrini kavrayamamaktadır. Ona göre öğretmenler, içeriğin kapsamının içeriğin öğretilmesi ile aynı olduğu fikrine sahip olma eğilimindedir. Bu konuda, Henke, Chen ve Goldinan (1999) tarafından ortaöğretim sosyal bilgiler öğretmenlerinin öğretim uygulamaları hakkında ulusal bir çalışma yürütülmüştür. Çalışmanın bulguları özellikle ortaöğretim sosyal bilgiler öğretmenlerinin diğer alandaki öğretmenlerle karşılaştırıldığında, tüm grup öğretimi yerine alternatif öğretim yöntemlerini kullanma olasılıklarının daha düşük olduğunu ortaya koymuştur. Yapılan çalışmada ayrıca sosyal bilgiler öğretmenlerinin çoğunun (\%91) hatırlamayı gerektiren sorular sorduğu, sadece küçük bir kısmının (\%38) haftalık olarak öğrenci liderliğindeki tartışmaları gerçekleştirdiği bulgusuna ulaşılmıştır. Çalışmada sosyal bilgiler öğretmenlerinin çoğu içerik bilgisi için ders kitabına güvendiğini belirtmiştir; öğretmenlerin çoğunun öğrencilerin kitaptan sınıfta okuma (\%94'ü) ve dişarıda okuma (\%95'i) yapmalarını istedikleri bulgusuna ulaşılmıştır. Ayrıca çalışmada, sosyal bilgiler öğretmenlerinin \%95'i haftalık olarak teknolojiyi kullandığını bildirmiştir; ancak, bu "teknolojinin" beyaz tahta ve tepegöz ile sınırlı olduğu bulgusuna ulaşılmıştır. Benzer şekilde İlter (2017) ve Russell'1n (2010), 21. yüzyılda sosyal bilgiler derslerinin nasıl öğretildiğini inceledikleri çalışmaların sonuçları, sosyal bilgiler öğretmenlerinin pasif öğrenmeyi teşvik etme konusunda daha meyilli olduklarını, aktif öğrenmeye daha az yatkın olduklarını göstermiştir. Russell'ın (2010) yürüttügüu çalışmanın bulguları derslerde çoğu zaman öğrencilerin üretken olmadığı, eleştirel düşünmeleri veya problem çözmeleri gerekmediğini göstermektedir. Eleştirel düşünme ve diğer karar verme becerileri, başarılı bir sosyal bilgiler eğitimi için çok önemlidir. Engle'a (2003) göre, eleştirel düşünme ve karar verme sosyal bilgiler eğitiminin kalbidir. Ayrıca, Russell'ın (2010) yürüttüğü çalışmada 
katılımcıların \%90'ını tarafından sosyal bilgiler dersinin yaklaşık yarısı ya da daha fazla bir bölümünde anlatım yönteminin kullanıldığını, zamanın büyük bir kısmının not almaya harcandığını ve öğretmenlerin ders kitaplarını birincil bilgi kaynağı olarak tercih ettiklerini göstermiştir. Russell (2010) ve Cuban'nın (1991) bulguları sosyal bilgiler öğretmenlerinin amacı, öğrencileri 21. yüzyılın etkili vatandaşları haline getirmek olmasına rağmen, sosyal bilgiler öğretmenlerinin bu hedefi gerçekleştirme potansiyellerini en üst düzeye çıkaramadıklarını ortaya koymaktadır. Bu çalışmanın bulguları da ilk ve orta öğretimde olduğu gibi sosyal bilgiler öğretmenliği lisans programında da aynı problemlerin hala yaşandığını ortaya koymuştur.

\section{Öneriler}

Sosyal bilgiler dersinde ilgi çekici ve anlamlı öğrenme firsatlarının olmayışı büyük bir eksikliktir. Öğrencilere, bir dizi öğrenme deneyimi ve eleştirel düşünmeleri için yeterli firsatlar sunmak, modern topluma aktif olarak katkıda bulunabilecek iyi ve etkili 21. yüzyı1 vatandaşlarını hazırlamak için temel bir unsurdur. Sosyal bilgiler öğretmen adaylarının eğitim öğretim süreçleri planlanırken 21. yüzyıl becerilerini kapsayan ve öğrenme ortamlarını temel alan dersler konulmalıdır. Öğretmen eğiticilerinin sundukları eğitsel yaşantılar, öğretmen adaylarının 21. yüzyıl becerilerini kullanmaları için model olmalıdır. Öğretmen eğitimcilerinin ne öğretildiği kadar içeriğin nasıl öğretildiğinin de önemli olduğu fikrini kavramaları önem arz etmektedir. Özellikle de öğretmen eğitimi programlarında bu beceri ve yetkinlikleri hedef alan detaylı bir programa ve değerlendirmelere yer verilmelidir.

Son olarak, tüm bu beceriler ancak öğretmenler ve öğrenciler onları öğretme ve öğrenme deneyimleriyle değerli ve ilgili gördükleri takdirde uygulamaya konulabilir. Öğretmen eğitimi programları bunun için kilit rol oynamaktadır. Özellikle öğretmen adaylarının, öğrencilerinin bu becerileri geliştirmelerine nasıl yardımcı olacakları konusunda eğitim almalarının yanı sıra, bu becerilerin değerine ikna olmaları ve onlara yeterli zaman ayırmaları için teşvik ve kaynaklar sağlanması gerekir. 


\section{Kaynakça}

AASL (American Association for School Librarians). (2007). The American Association for School Librarians Standards for the 21st Century Learner. Chicago: The American Association for School Librarians. [Çevrim-içi: https://www.epsnj.org/site/handlers/filedownload.ashx?moduleinstanceid=7770\&dat aid=32216\&FileName=AASL\%2021ST\%20C\%20LEARNER.pdf], $\quad$ Erişim tarihi:12.06.2020

Aktay, S. (2016). The ISTE national educational technology standards and prospective primary school teachers in Turkey. The International Journal of Learning, 16(9), 127-138.

Ananiadou, K., \& Claro, M. (2009). 21st century skills and competences for new millennium learners in OECD countries, OECD Education Working Papers, No. 41, OECD Publishing. [Çevrim-içi: http://dx.doi.org/10.1787/218525261154], Erişim tarihi:24.08.2020

Bernhardt, E. P. (2015). 21st century learning: Professional development in practice. The Qualitative Report, 20(1), 1-19.

Binkley, M., Erstad, O., Herman, J., Raizen, S., Ripley, M., Miller-Ricci, M. \& Rumble, M. (2012). Defining twenty-first century skills. In P. Griffin, B. McGaw \& E. Care (Eds.), Assessment and teaching of 21st century skills (pp. 17- 66). New York: Springer.

Büyüköztürk, S., Akgün, Ö. E., Özkahveci, Ö., \& Demirel, F. (2004). The validity and reliability study of the Turkish version of the motivated strategies for learning questionnaire. Educational Sciences: Theory \& Practice, 4(2), 207-239.

Büyüköztürk, Ş., Kılıç Çakmak, E., Akgün, Ö.E., Karadeniz, Ş. ve Demirel, F. (2008). Bilimsel araştırma yöntemleri (14. Bask1). Ankara: Pegem Yayınları

Clark, D. D. (2008). A study of West Virginia teachers: Using 21st century tools to teach in a 21 st century context. Unpublished doctoral thesis. Marshall University, West Virginia.

Creswell, J. W. (2008). Educational research planning, conducting and evaluating quantitative and qualitative research. International Pearson Merril Prentice Hall. 
Çakır, A. \& Güngör, M.N. (2017). Pre-service teachers' evaluations of practices in teaching english to young learners in terms of 21 st century teacher qualifications. Journal of Language and Linguistic Studies, 13(1), 244-259.

Çoklar, A.N. (2008). Öğretmen adaylarının ĕgitim teknolojisi standartları ile ilgili özyeterliklerinin belirlenmesi. Yayınlanmamış doktora tezi. Anadolu Üniversitesi, Eğitim Bilimleri Enstitüsü, Eskişehir.

Darling-Hammond, L. (2006). Constructing 21st-century teacher education. Journal of Teacher Education, 57(X), 1-15 doi: 10.1177/0022487105285962

EARGED (2011). MEB 21. yüzyıl öğrenci profili. Ankara: MEB. [Çevrim-içi: https://www.meb.gov.tr/earged/earged/21.\%20yy_og_pro.pdf],__Erişim tarihi: 05.06 .2020

Engle, H. S. (2003). Decision Making: The Heart of Social Studies Instruction, The Social Studies, 94(1), 7-10.

Fraenkel, J. K, \& Wallen, N. E. (1996). How to design and evaluate research in education (third edition). New York: McGraw-Hill, Inc.

Geisinger, F. K. (2016). 21st century skills: What are they and how do we assess them? Applied Measurement in Education, 29(4), 245-249.

Göksun, O. D. (2016). Öğretmen adaylarının 21. yy. ögrenen becerileri ve 21. yy. öğreten becerileri arasındaki ilişki. Yayınlanmamış doktora tezi. Anadolu Üniversitesi, Eğitim Bilimleri Enstitüsü, Eskişehir.

Gürültü, E., Aslan, M., \& Alcı, B. (2019). Ortaöğretim öğretmenlerinin 21. yüzyıl becerileri kullanım yeterlikleri. Hacettepe Üniversitesi Ĕ̌itim Fakültesi Dergisi. Advance online publication. DOI: 10.16986/HUJE.2019051590

Hamarat, E. (2019). 21. yüzyıl becerileri odă̆ında Türkiye’nin eğitim politikaları, SETA Yayınları, [Çevrim-içi: https://setav.org/assets/uploads/2019/04/272A.pdf],_Erişim tarihi: 05.06.2020

Henke, R., Chen, X., \& Goldman, G. (1999). What happens in the classroom? Instructional practices in elementary and secondary schools, 1994-95. Washington, DC: National Center for Education Statistics. (ERIC Reproduction No. EW31735) [Çevrim-içi: https://nces.ed.gov/pubs99/1999348.pdf],_Erişim tarihi: 17.05.2020 
F.Bozkurt/ Pamukkale Üniversitesi Eğitim Fakültesi Dergisi, 51, 34-64, 2021

İlter, İ. (2017). Öğretmenlerin sosyal bilgiler derslerinde öğretim yöntemleri ve uygulamaları üzerine bir değerlendirme. Kuramsal Eğitimbilim Dergisi, 11(1), 1-29.

Jia, Y., Oh, J.Y., Sibuma, B., LaBanca, F. \& Lorentson, M. (2016). Measuring twenty-first century skills: development and validation of a scale for in-service and pre-service teachers. Teacher Development, 20(2), 229-252.

Karasar, N. (2018). Bilimsel araştırma yöntemi. Ankara: Nobel Yayıncılık.

Kereluik, K., Mishra, P., Fahnoe, C. \& Terry, L. (2013). What knowledge is of most worth. Journal of Digital Learning in Teacher Education, 29(4), 127-140.

Larson, C. L. \& Miller, N. T. (2011). 21st century skills: Prepare students for the future. Kappa Delta Pi Record, 47(3), 121-123.

Niemi, H., Pehkonen, L., Niu, J., Teng, J, \& Harju, V. (2018). How do teacher education programs guide student teachers to gain the 21st century skills? Unpublished doctoral thesis, Faculty of Educational Sciences, University of Helsinki.

Pallant, P. (2017). SPSS kullanma kılavuzu SPSS ile adım adım veri analizi. S. Balcı ve B. Ahi, (Çev.). Ankara: Anı Yayıncılık.

Russell, B. W. (2010). Teaching social studies in the 21st century: A research study of secondary social studies teachers' instructional methods and practices. Action in Teacher Education, 32(1), 65-72.

Schermelleh-Engel, K., Moosbrugger, H., \& Müller, H. (2003). Evaluating the fit of structural equation models: Tests of significance and descriptive goodness-of-fit measures. Methods of Psychological Research Online, 8(2), 23-74.

Schumacker, R. E., Lomax, R. G. (2010). A beginner's guide to structural equation modeling ( $3^{\text {rd }}$ Edition). New York: Routledge/Taylor \& Francis Group.

Seçer, İ. (2015). SPSS ve LISREL ile pratik veri analizi (Genişletilmiş 2. baskı). Ankara: Anı Yayınc1lik.

Silva, E. (2009). Measuring skills for 21st century learning. Phi Delta Kappan, 90(9), 630634.

Şahin, M. C. (2010). Eğitim fakültesi öğrencilerinin yeni binyılın ögrrencileri (OECD New millenium learners) ölçütlerine göre değerlendirilmesi. Yayınlamamış doktora tezi, Anadolu Üniversitesi Eğitim Bilimleri Enstitüsü, Eskişehir. 
The Partnership for 21st Century Learning. (2007). Framework for 21st century learning. Washington, DC. [Çevrim-içi: http://www.battelleforkids.org/learning-hub/learninghub-item/framework-for-21st-century-learning-definitions],_Erişim tarihi: 30.07.2019

UNESCO-United Nations, Educational, Scientific and Cultural Organization. (2014). Guiding Principles for Learning in the Twenty-first Century. [Çevrim-içi: http://www.ibe.unesco.org/sites/default/files/resources/practices_series_28_v3_002.p df ],_Erişim tarihi: 10.07.2020

Urbani, M.J., Roshandel, S., Michaels, R. \& Truesdell, E. (2017). Developing and modeling 21st-century skills with preservice teachers, Teacher Education Quarterly, Fall. 
F.Bozkurt/ Pamukkale Üniversitesi Eğitim Fakültesi Dergisi, 51, 34-64, 2021

Ek 1. 21. Yüzyll Becerileri Ölçeğine İlişkin DFA t değerleri

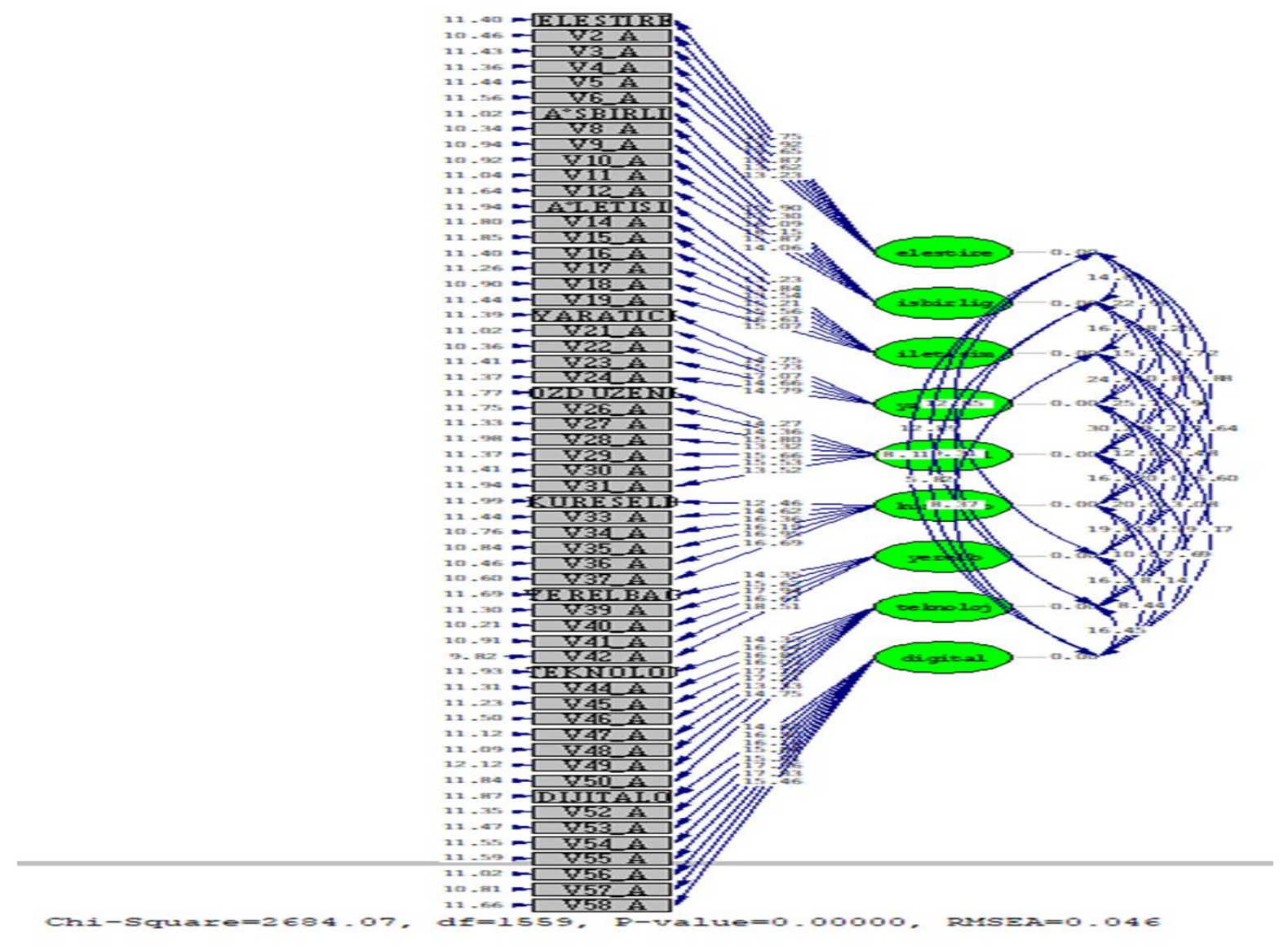


Ek 2. 21. Yüzyll Becerileri Ölçeğine İliş̧kin DFA faktör yükü değerleri

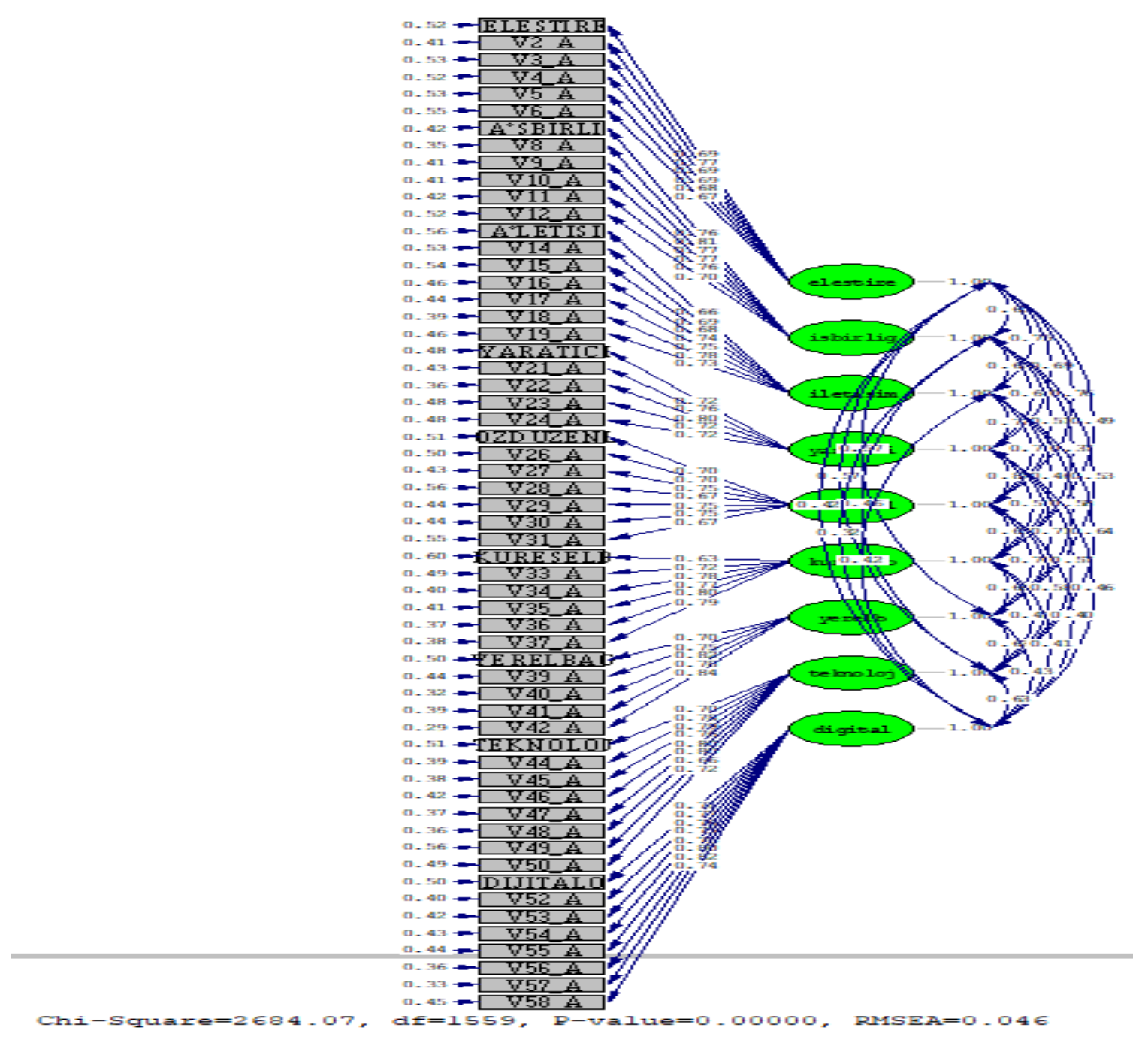

